\title{
Do social conditions matter for emergence of innovative firms? The case of Kosovo
}

\author{
Fadil Sahiti \\ Rochester Institute of Technology in Kosovo, \\ Gërmia Campus, Dr. Shpëtim Robaj st. nn, \\ 10000 Prishtina, Republic of Kosovo \\ Email: fxscad1@rit.edu
}

\begin{abstract}
The theory of innovative enterprise emphasises the importance of social conditions in the capabilities of firms to innovate. Firms operate in a particular social context characterised by national economic institutions that influence the social conditions of innovative activities. Governance institutions influence strategic control, employment institutions influence organisational integration, and investment institutions influence financial commitment. This paper examines whether these social factors matter for the emergence of innovative firms in the context of low-income economies, with evidence from Kosovo firms. The findings suggest that Kosovo's economy provides little incentives for firms to innovate. While the country has established an institutional framework which to a great extent is comparable to developed countries, the major challenge remains its enforcement. The number of business entities endowed with innovative capabilities is low, and this is an outcome of macro as well as micro social context.
\end{abstract}

Keywords: innovation; social conditions; strategic control; organisational integration; investment capabilities.

Reference to this paper should be made as follows: Sahiti, F. (2018) 'Do social conditions matter for emergence of innovative firms? The case of Kosovo', Int. J. Innovation and Regional Development, Vol. 8, No. 1, pp.75-101.

Biographical notes: Fadil Sahiti received his BSc in Economics from the Prishtina University in Kosovo, gained an MBA from the IUKB in Switzerland, and his PhD from the Birkbeck, University of London in the UK. His research interests lie in the field of entrepreneurship and innovation in less-developed economies. He is currently working as an Assistant Professor at the Rochester Institute of Technology (R.I.T), USA/Kosovo.

This paper is a revised and expanded version of a paper entitled 'The impact of social conditions on firm innovation' presented at Annual Conference of the UCL Centre for Comparative Studies of Emerging Economies, London, 26-27 June 2017.

\section{Introduction}

While internal factors such as organisational capabilities and good management practices may affect firm's ability to innovate, wider economic and social conditions in which companies operate can also enable or/and deter innovation efforts. In order to expand the 
number of firms with innovation capacities, it is critical to get the wider social conditions for innovation right. However, understanding which social conditions can spur or stifle innovation efforts, and how to influence them, remains a challenge.

The purpose of this paper is to assess the social conditions affecting firms' capacity to innovate, with evidence from Kosovo firms. The objective is to examine whether social conditions matter for the emergence of innovative firms. While there are many research studies which investigate the relationship between the innovative activity and the benefits of innovation to the economy, this paper focuses on the assessment of social conditions in which firms operate. This is important since social conditions are sort of variables which the government policies and managers can influence.

The utilised methodology follows two steps. The first step is to examine social conditions at macro level, and whether these conditions enable or constrain the capabilities of firms to innovate. Results obtained in this section are compared with other countries. The second step is to examine social conditions at firm level.

Findings indicate that Kosovo's economy provides a poor social environment for firms to innovate. While the country has managed to establish a business institutional framework which to a great extent is compatible with developed countries, the major challenge lies in the implementation in practice of this framework. The findings indicate that there is a set of social factors related to strategic control, organisational integration capabilities, and financial commitment that matter for the emergence of innovative firms. However, the number of firms in the country endowed with these social conditions conducive to innovation results is significantly low.

The process of analysis has been conducted by utilising diverse data and information obtained from different sources. Social conditions at national level have been examined by using data that were reported by various national and international sources, whereas social conditions at firm level were analysed by using a firm-level dataset, obtained from a survey conducted in 2012. The units of analysis are small and medium size enterprises (SMEs).

The contribution of this study to the existing literature of firm innovation is twofold. Firstly, it is clear that existing literature has significantly improved our empirical understanding of firm innovation determinants. But, the vast majority of research studies have been focused on developed economies. There is less evidence which could illuminate our knowledge about innovation determinants in low-income economies. By providing new evidence on the impact of social conditions on the firm innovation in low-income countries, this paper aims to bridge the gap marked in the literature of firm innovation. Secondly, this study is among the first ones using the theory of innovative enterprise as an organising framework to assess the impact of social conditions on the firm innovation. To the best knowledge, apart from the empirical study conducted by Lazonick et al. (2013) on Apple's changing business model, there are no other studies conducted to support empirically the propositions put forward by this theory.

The rest of the paper is organised as follows. Section 2 reviews the literature on the factors of firm innovation. Section 3 discusses the theoretical perspective, and proposes the hypothesis to be tested. In Section 4, the dataset is described and the methods used to study social conditions of firm innovation. Section 5 is provided a short overview on Kosovo's economic profile. Section 6 provides empirical results at the national level. Section 7 presents and discusses the main results at firm level. Section 8 provides a short discussion on the results. Finally, Section 9 concludes. 


\section{Review of literature}

The review of the literature is focused on recent research that provides evidence on the relationship between external/internal factors and innovation activities for SMEs. The evidence suggests that, for SMEs there is a strong positive relationship between exporting and innovation activity (Golovko and Valentini, 2011). SMEs with capabilities to innovate are more likely to export, and more likely to generate growth from exporting than non-innovating firms (Love and Roper, 2013; Melkas and Pekkarinen, 2016; Shapira et al., 2011). In addition, evidence indicates that SMEs that export are three times more likely to introduce products or services that are new to their sector than those which are entirely domestic in orientation (EC, 2010).

Various studies have widely discussed the strengths and weaknesses of smaller firms relative to larger ones in terms of innovation and exporting. The evidence suggests that smaller firms have advantages when it comes to quick decision making, willingness to take risk and flexibility in responding to new market opportunities; whereas larger firms have advantages linked to scale and the availability of specialist resources (Love and Roper, 2013; Murphree et al., 2016). Further, the evidence indicates that the relative strengths of large business are predominantly material, i.e., strengths related to economies of scale and scope, financial and technological resources, etc., whereas those of small firms are mostly behavioural, i.e., strengths related to entrepreneurial dynamism, flexibility, efficiency, proximity to the market, motivation (Vossen, 1998).

With regard to internal enablers of firms' innovation/exporting, studies have used various variables such as the skills of the workforce, managerial and marketing skills, education and workforce diversity, capital investment, business strategy, internal finance, R\&D, ownership, etc. There is a broad agreement that firms require distinctly different skill sets to be successful in innovation and exporting business activities (Barney, 1991; Leiponen, 2005; Freel, 2005; Bloom and Van Reenen, 2007; Herrmann and Peine, 2011). Also empirical evidence emphasises the importance of the national 'skills ecosystem' and related legal, vocational education and industrial relation systems for innovation (Cooney, 2010). Evidence points out that partnering or collaborative working for innovation offer potential route for accessing external skills and so overcoming internal skill constraints (Love and Roper, 2013). Evidence shows that there is a positive relationship between innovation and workforce educational diversity (Østergaard et al., 2011; Nathan, 2013). Some other studies have investigated also the relationship between ownership structure and the innovation processes (Love et al., 2009).

Recent empirical evidence suggests a positive link between fixed capital investment and innovation. For example, Pellegrino et al. (2009) provide evidence on how for small firms purchases of machinery and equipment are the crucial driver of innovative outputs. A number of studies have investigated the role of internal financing on innovation activities, indicating that the internal funding is more important for innovation in smaller firms than for larger companies, perhaps reflecting stronger constraints to external finance by smaller firms (Ughetto, 2008). There have been studies with focus on the role of business strategy and innovation, and the role of ownership such as family owned business and their impact on innovation activities. With regard to the link between business strategies and innovation, the current state of knowledge is characterised by conflicting theoretical predictions, persisting knowledge gaps and theoretical inconsistencies (Keupp et al., 2012). While some recent empirical evidence casts doubt 
on the positive link between innovation and family owned firms, there is some evidence which argues that family ownership is positively related to firms' ability to sense innovation opportunities and organisational innovation (Bresciani et al., 2013; Lichtenthaler and Muethel, 2012; Classen et al., 2012).

With regard to the impact of external factors/enablers on the innovation capabilities, broadly there are two main categories of external enablers discussed by research studies: external factors which may enhance or augment the knowledge base for firms and hence provide the basis for innovation; and, resource augmenting factors which may help firms to overcome internal resource constraints (Kanter, 2000; Hausmann et al., 2008; Love and Roper, 2013; Rodríguez at al., 2014). Recent research distinguishes three main channels through which firms may obtain external knowledge which may contribute to their innovation activity: flows of local knowledge or information mediated through social contacts or labour market linkages, partnering in which firms engage in deliberate relationships with other organisations in order to gather either technical knowledge or market understanding, and knowledge through their exporting activities (Freeman et al., 2012; He and Wong, 2012; Gust-Bardon, 2014). There is more specific evidence explaining how some external linkages have a greater impact on firm's innovation and exporting than others, a special emphasis is put on the link between firms' clients and suppliers. For example, a recent study of 1,500 European SMEs finds that customers are often an attractive source of innovation inputs (Brunswicker and Vanhaverbeke, 2011). Collaborative relationships between firms and other research organisations may also play a significant role in easing the resource constraints faced by smaller firms. In this respect, the role of central governments facilitating the resource issue of smaller firms is often emphasised in the form of public sector grants or loans (Hewitt-Dundas and Roper, 2009).

In summary, despite the fact that over the last decade a considerable progress has been made to improve our understanding of the internal and external enablers and/or constraints of innovation/exporting, yet the evidence base is either inconsistent or limited in some areas. For instance, majority of papers have been focused developed countries and large firms. There is little consensus on what needs to be done and which approaches to employ in order to better understand the dynamic interaction between external and internal factors influencing firm innovation in developing countries, and specifically in low-income countries and for SMEs. Firms, particularly SMEs are complex entities which do not necessarily grow and innovate once external constraints or internal capabilities are improved, as for instance growth diagnostics approach or the resource-based theory and managerial practices approach would argue. None of these frameworks look at innovation and growth capabilities of firms in dynamic way. There is a need for a perspective which integrates both factors into a single theoretical framework, and in this way enable to better understand the dynamic interaction between the organisational conditions and the institutional environments in which firms operate.

\section{Theoretical perspective}

To investigate social conditions conducive for innovation, the theory of the innovative enterprise advocated by Lazonick (2012), provides a useful analytical framework. The theory focuses on three social conditions, namely strategic control, organisational 
integration, and financial commitment. Through their interaction, these conditions define the operation and determine the performance of a business enterprise. The need for these social conditions derives from the uncertain, collective and cumulative character of the innovation process. ${ }^{1}$ These characteristics of the innovation process vary markedly across different industrial sectors with different types of markets that must be accessed, technologies that must be transformed, and competitors with which the innovative enterprise must compete, as it seeks to generate a product that is higher quality and lower cost than previously available (Lazonick, 2013). Firms operate in a particular social context characterised by national economic institutions that influence the social conditions of innovative activities. For instance, governance institutions influence strategic control, employment institutions influence organisational integration, and investment institutions influence financial commitment. In the words of Lazonick (2013), this framework confronts both, the ill-conceived and highly ideological neoclassical theory, and transaction cost theory, by offering a rigorous alternative to the foundations of economic analysis, relevant to not only economists but also others such as social scientists, business academics, industry analysts, etc. ${ }^{2}$ Operationalisation of social indicators into specific indicators and variables is provided in Figure 1.

Figure 1 List of indicators and variables

\begin{tabular}{|c|c|c|c|}
\hline Indicators & Variables & Themes & Proxies used \\
\hline \multirow{3}{*}{$\begin{array}{l}\text { Social conditions at } \\
\text { national level }\end{array}$} & Governance institutions & $\begin{array}{l}\text { Involves issues related to the } \\
\text { regulatory framework. }\end{array}$ & The enterprise/firm law, and tax laws. \\
\hline & Employment institutions & $\begin{array}{l}\text { Covers aspects related to } \\
\text { employability. }\end{array}$ & $\begin{array}{l}\text { Employment law, labour market flexibility, } \\
\text { easiness to hire or lay-off employees, and } \\
\text { reward systems. }\end{array}$ \\
\hline & Investment institutions & $\begin{array}{l}\text { Cover aspects related to the system } \\
\text { which ensures that sufficient financial } \\
\text { resources are available on a } \\
\text { continuing basis to sustain the } \\
\text { development of innovative } \\
\text { capabilities. }\end{array}$ & $\begin{array}{l}\text { External financing through eqiuty, and external } \\
\text { financing through debt. }\end{array}$ \\
\hline \multirow{3}{*}{$\begin{array}{l}\text { Social conditions at } \\
\text { firm level }\end{array}$} & The strategic control & $\begin{array}{l}\text { Covers a set of relations that give } \\
\text { power to those that take decisions to } \\
\text { allocate the firm's resources to } \\
\text { confront the technological, market, } \\
\text { and competitive uncertainties } \\
\text { inherent to innovation process. }\end{array}$ & $\begin{array}{l}\text { - Structure and characteristics of the ownership, } \\
\text { - Relationship between owners and managers, } \\
\text { - Concentration of ownership (minorities and } \\
\text { majority owners), } \\
\text { - Interactions between managers and owners } \\
\text { - Abilities of those who have power to take } \\
\text { decisions (educational attainment of decision- } \\
\text { makers, experiences collected over the years, } \\
\text { and training received) }\end{array}$ \\
\hline & $\begin{array}{l}\text { The organisational } \\
\text { integration }\end{array}$ & $\begin{array}{l}\text { Covers relations that enable firms to } \\
\text { transform inputs into innovative } \\
\text { outputs. }\end{array}$ & $\begin{array}{l}\text { - The learning sources, i.e. learning from } \\
\text { supplier, competitors, consumers; } \\
\text { - Internal learning from the experience of } \\
\text { workers; } \\
\text { - The way how the innovation process is } \\
\text { organised, i.e. innovation processes organised } \\
\text { independently or in collaboration with other } \\
\text { external entities (academic institutions and } \\
\text { research institutions, business associations). }\end{array}$ \\
\hline & Investment capabilties & $\begin{array}{l}\text { Covers aspects related to availability } \\
\text { of financial resources to commit } \\
\text { during the innovation processes }\end{array}$ & $\begin{array}{l}\text { - Amount of investments committed by firms in } \\
\text { last three years, } \\
\text { - The investment funds raised from banks, and } \\
\text { - The terms and conditions in which funds were } \\
\text { raised from banks. }\end{array}$ \\
\hline
\end{tabular}

Drawing upon all these, the following is the research question: do social conditions matter for the emergence of innovative firms in Kosovo? 
The main hypothesis is: the emergence of innovative firms that operate in Kosovo's economy is the function of social conditions at macro as well as micro level.

\section{Methodology and data}

Before reviewing the methodology and data, it is worth clarifying what is meant by the concept of innovation. The perspective on innovation here is deliberately broad, suggested by OECD (2013b) which segments the innovation into four major areas: product, process, marketing, and organisational. ${ }^{3}$ In the absence of any data on innovation activities of firms in Kosovo, exporting is considered as a proxy for innovation. Innovation is treated as products and processes new to the firm, not necessarily new to the national or international market. So, innovation is firm and market driven activity which is quite close to firms' daily activities and in the case of Kosovo as a rule does not involve major R\&D effort. The units of analysis are small and medium size firms (SMEs) operating in the Kosovo's economy. The term exporting here is used in its normal sense of outward international trade in goods and/or services, conducted either directly or through a third party (Jones, 2001).

The methodology used to analyse the data has followed two steps. First, in the section where national social conditions are discussed, the analysis is merely descriptive. Data regarding the governance, employment, and investment institutions are analysed and put in the comparison to other countries in the region and wider. The aim was to examine how much this environment promotes or constraints the emergence of innovative enterprises. Investigation was carried out utilising data reported by national and international institutions such as the World Bank, OECD, UNESCO, and data from official institutions of Kosovo.

Second, investigation of social conditions at micro level was conducted by utilising a dataset generated from a firm-level survey. Aiming to identify whether social conditions at firm level influence the capabilities of firms to innovate, and specifically identifying which social conditions have more impact on differentiation between innovating and noninnovating firms, a dummy variable of two separate groups of firms was created. Since exporting is taken as proxy for innovation, one group of firms is made of exporting, while the other one of non-exporting firms. This method enables to separate patterns that are more general, isolate regularities that are different between two sample groups, and reveal those unique aspects of firms that probably are more difficult to see otherwise (Collier, 1993). More detailed information about dataset, including the used questionnaires, is provided in Appendix A. In order to reveal which social factors are more likely to differentiate two groups of firms, the logistic regression technique was applied (more detailed is provided in Appendix C).

\section{An overview of economic profile of Kosovo}

Kosovo is the youngest independent country in Europe. It declared independence in 2008 and it is recognised as an independent country by the 114 out of 193 UN members and by 23 out of 28 EU members. It has a population of 1.8 million.

Although from a low base, the economy of the country has had a consistently higher growth rate in the post-global financial crisis period than the Western Balkan country 
average (World Bank, 2016a, 2016b). Kosovo's GDP per capita grew from $\$ 1,088$ in 2000 to $\$ 3,641$ in 2016. Despite this tripling of income per capita, Kosovo remains among the poorest country in Europe, and it is listed by the World Bank in the group of lower-middle-income economies-with GNI per capita between $\$ 1,006$ to $\$ 3,975$.

According to World Bank (2016a, 2016b) reports, during 2008-2016 the real GDP grew on average by $3.4 \%$, which was primarily driven by consumption and an investment-driven recovery in domestic demand. The economy is highly dependent on remittances and international aid. These two components account for $22.5 \%$ of total GDP (remittances between 10-15\%, while international aid and donor-funded activities account for another $7.5 \%$ of the GDP) (USAID, 2010). Services represent the largest sector in the economy, with a share of value added at 54\% of GDP during 2008-2015 (World Bank, 2016a, 2016b). Industry is relatively small by regional standards at $16 \%$ of GDP, of which manufacturing is about $10 \%$. Agriculture remains relatively large at $11 \%$ of GDP. The structure of firms is dominated by small firms that employ 1 to 9 employees, comprising an absolute majority of firms-98.39\% of total firms (World Bank, 2016a, 2016b).

Country is characterised by a macroeconomic stability, which is primarily based on full euroisation, a fiscal policy that follows a fiscal rule, and on a healthy financial sector dominated by the banking sector, which is well capitalised and profitable (World Bank, 2016a, 2016b).

\section{Empirical results at the national level}

As stated above, the theory of innovative firms links into pair interaction governance institutions with strategic control, national employment institutions with organisational integration, and investment institutions with financial commitment. The following analysis will be focused on the component of governance institutions.

Governance institutions influence strategic control. This component of social conditions determines how a society assigns rights and responsibilities to different groups of people over the allocation of its productive resources, and how it imposes restrictions on the development and utilisation of these resources. More specifically, this component of social conditions has to do with regulatory framework for firms, governance elements, and tax laws.

A number of recent international reports point out that Kosovo's regulatory framework on business firms is by and large modern and compatible with European and international standards (EBRD, 2013; World Bank, 2016a). This framework regulates various aspects related to business organisations, including the types of business activities that can be conducted, determines the applicable registration requirements for each type of business entity, specifies in detail the rights and obligations of owners, shareholders, managers, directors, legal representatives and third parties. Though certain gaps still need to be filled with new laws and secondary legislation, the overall impression is that the main gap to be bridged is between the relatively advanced legislation and the level of its implementation. ${ }^{4}$ There is a specific framework which regulates aspects linked to accounting, financial reporting, and auditing, including corporate governance issues (http://www.kuvendikosoves.org/common/docs/ligjet/Law\%20on\%20accounting\%20fina nc\%20reporting\%20and\%20audit.pdf). Corporate governance is a relatively new concept 
in Kosovo, and despite substantial improvements made by the government, the main problem remains implementation, which still lags behind other countries (EBRD, 2013). With regard to how easy is for firms to pay taxes, globally, Kosovo stands at 67 in the ranking of 189 Economies - see Figure 2.

Figure 2 Kosovo and comparator economies rank on the ease of paying taxes-2016 (see online version for colours)

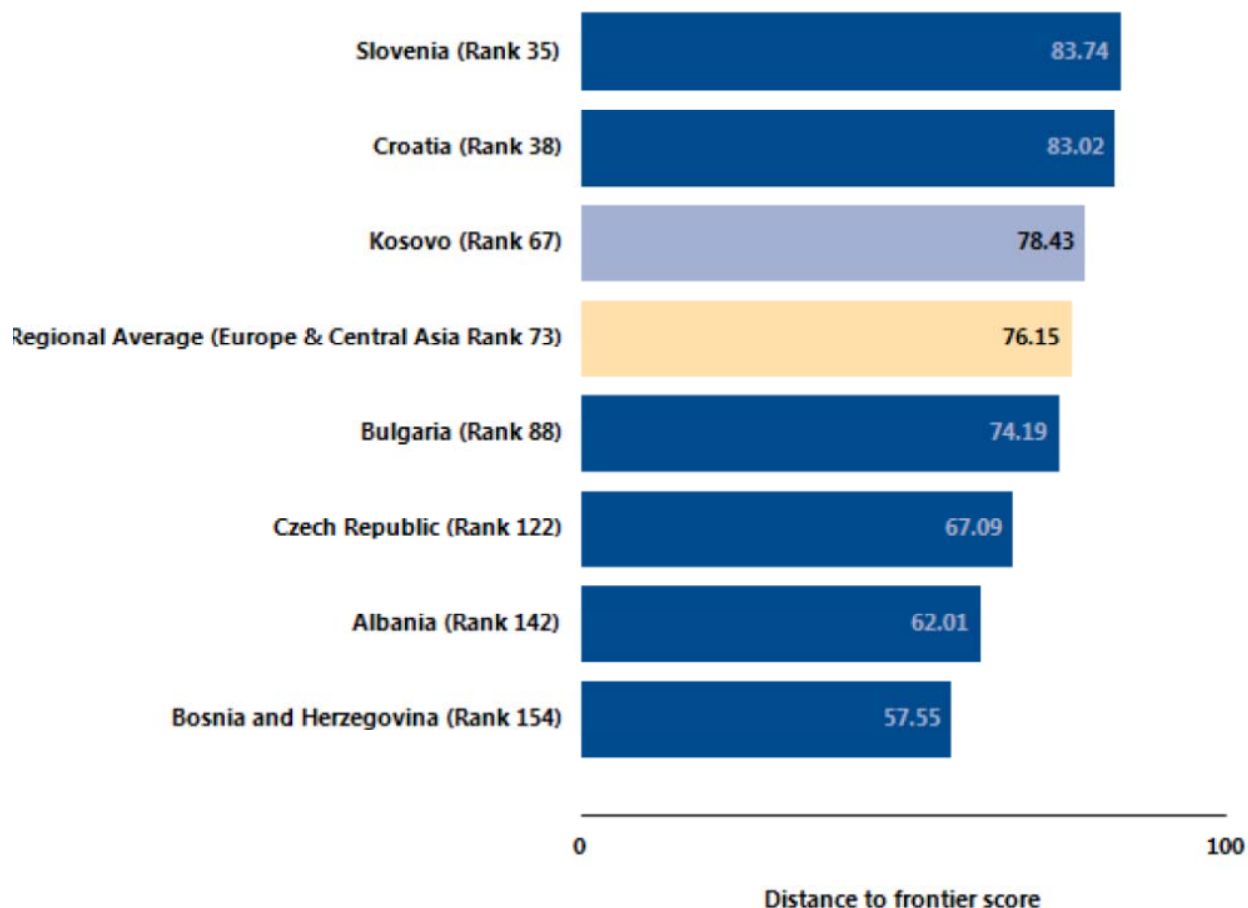

Source: Doing business database

The second element of social conditions at the national level is related to the employment institutions, which influence organisational integration. Among other aspects, this component contains aspects on how society provides the population with education, training, and access to research. Other aspects include issues on employment law, labour market flexibility, easiness to hire or lay-off employees, and reward systems. The following analysis is focused on the quality of educational system, followed by the analysis of the state of research and innovation system in the country.

The education system in Kosovo consists of nine years of compulsory basic education, supplemented by three to four years of non-compulsory upper secondary education. Upper secondary education is divided into general education and vocational schools. In Kosovo, 43\% of students entered vocational schools in 2009-2010, this is fairly low when compared to $71 \%$ in Croatia and 61\% in FYR Macedonia. In 2011, $8 \%$ of the overall population had a university degree compared to an average of $34 \%$ in EU-27 countries, 23\% in Croatia, and 17\% in FYR Macedonia (OECD, 2011).

Higher education institutions are seen as important players in innovation systems as they generate and train scientists, managers and engineers, thus adding to the knowledge 
base of an economy (Fagerberg, 2001). In Kosovo, majority of students enrol in social sciences rather than, for instance, engineering, manufacturing, or construction. Findings provided by OECD (2013b) indicate that only $5.6 \%$ of the enrolled students are studying natural and mathematical sciences and 3.4\% electrical and computer engineering. By contrast, in the Former Yugoslav Republic of Macedonia 11.6\% of students are studying sciences and $7.7 \%$ fields related to engineering, manufacturing and construction; while the figures are $7.8 \%$ (sciences) and $12.2 \%$ (engineering, manufacturing and construction) for Croatia (UNESCO, 2012). Though the enrolment rate in higher education has been increased, Kosovo lags behind other economies in the region in terms of university graduates. $8.2 \%$ of the population in Kosovo holds a university degree, which is significantly lower than Croatia $(24.5 \%)$ and the Former Yugoslav Republic of Macedonia (20.4\%) (UNESCO, 2012).

There is a general view among firms that students that graduate in the Kosovo's universities, both private and public ones, lack applied skills (OECD, 2013a). ${ }^{5}$ This is so, because the education system, especially in the public universities, has been predominantly theoretical for decades. Practical work or internships are not obligatory for students, and even if students have the opportunity to gain some professional experience, internships are often limited to only a few weeks (OECD, 2013a). Without applied skills and soft skills acquired during the studying period, the entry of students to the labour market is hampered (OECD, 2013a). According to the EC (2012), over 70\% of Kosovo's population is under the age of 30 while its youth unemployment rate of $73 \%$ is the highest in South East Europe. World Bank (2010) indicates that the share of employees with university degrees or higher ones in Kosovo is twice lower (7\%) than in SouthEastern European (SEE) region (15\%), and three times lower compared with the Europe and Central Asia (ECA) region $(24 \%)^{6}$

Figure 3 Problems of doing business: skills and education* (see online version for colours)

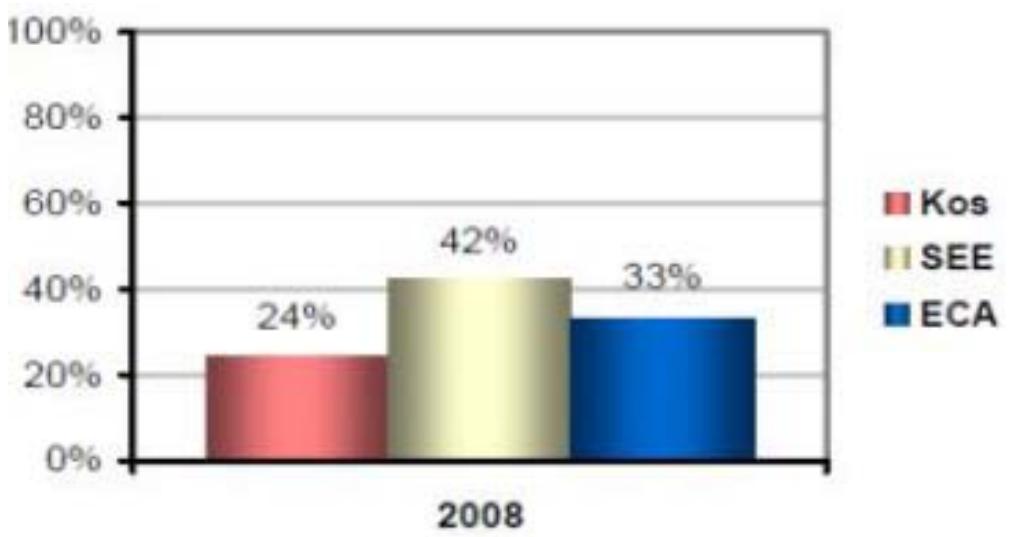

Note: *Percentage of firms indicating that skills and education of available workers is not a problem.

Source: World Bank (2010)

With regards to training activities organised by firms, the same report indicates that percentage of firms in Kosovo offering training activities for their employees is $25 \%$ comparing to $32 \%$ in SEE, and $35 \%$ in ECA region. Percentage of employees that 
participate in training in the production sector for firms that operate in Kosovo is significantly lower with only $9 \%$, comparing to SEE with $46 \%$, and ECA region with $36 \%$ (see Appendix B).

Regarding the research and innovation institutions at macro-level, findings indicate that number of such institutions in Kosovo is very low, and moreover those that exist suffer from a lack of research capacity and applied research is under-developed (OECD, 2013a). Also the level of commercialisation of research results is insignificant, as is cooperation between science and industry in general (OECD, 2013a). Table 1 shows that Kosovo is at the lower end of comparator countries with only 0.10 of gross expenditures on R\&D as percentage of GDP.

Figure 4 Gross expenditure on R\&D (2010) (see online version for colours)

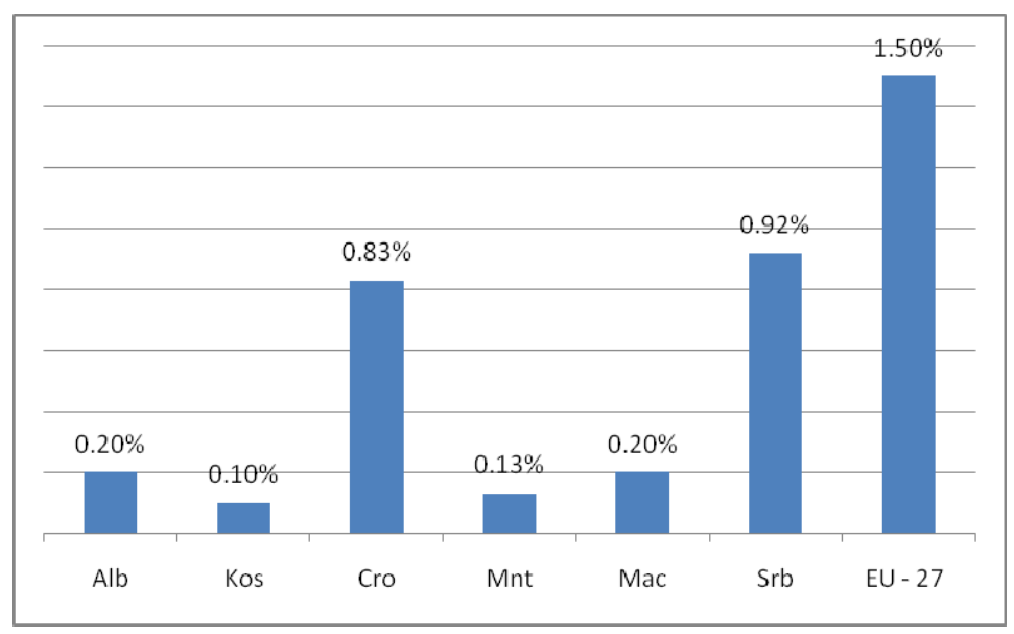

Source: OECD (2013a)

Kosovo has adopted legislation related to employment and labour relations, which in general is in line with European Union standards (http:/www.kuvendikosoves.org/ common/docs/ligjet/2010-212-eng.pdf). This law ensures four fundamental principles including: freedom of association and recognition of the right for collective negotiations, elimination of any kind of forced or violent labour, elimination of child labour, and elimination of discrimination at work. In one of the recent reports issued by European Commission (2012), the implementation of this law remains quite limited, and the labour market in the country remains dysfunctional and characterised by widespread informality. The current labour legislation provides simple procedures and low costs for firms hiring and firing (World Bank, 2010). Despite the fact that hiring and firing is relatively easy, this legislation has significant limitations when it comes to flexible work arrangements (World Bank, 2010). For instance, there are some restrictions on fixed-term contracts, part-time work, working from home, alternative work schedules, overtime and night work.

The third element of the social condition at the macro-level is related to investment institutions. These institutions influence financial commitment. This social component deals with aspects such as how are financial resources mobilised in the economy for 
investments in productive resources, from what sources and on what terms, what is the relation between equity and debt in financing investment.

With regard to the ways in which firms finance their business activities, the enterprise survey conducted by the World Bank (2013) BEEPS provides indicators on how firms manage to obtain the necessary funds to finance their operations and of the characteristics of their financial transactions. As Figure 5 shows, around $73 \%$ of business activities are financed by internal funds, $17 \%$ from bank finance, $5 \%$ from equity, and sale of stocks, while the rest comes from other sources. According to these figures, firms in Kosovo use more internal sources to finance their investments than other countries in the ECA region, and less than other low income countries.

Figure 5 Source of finance for investment purposes in Kosovo and comparator countries (see online version for colours)

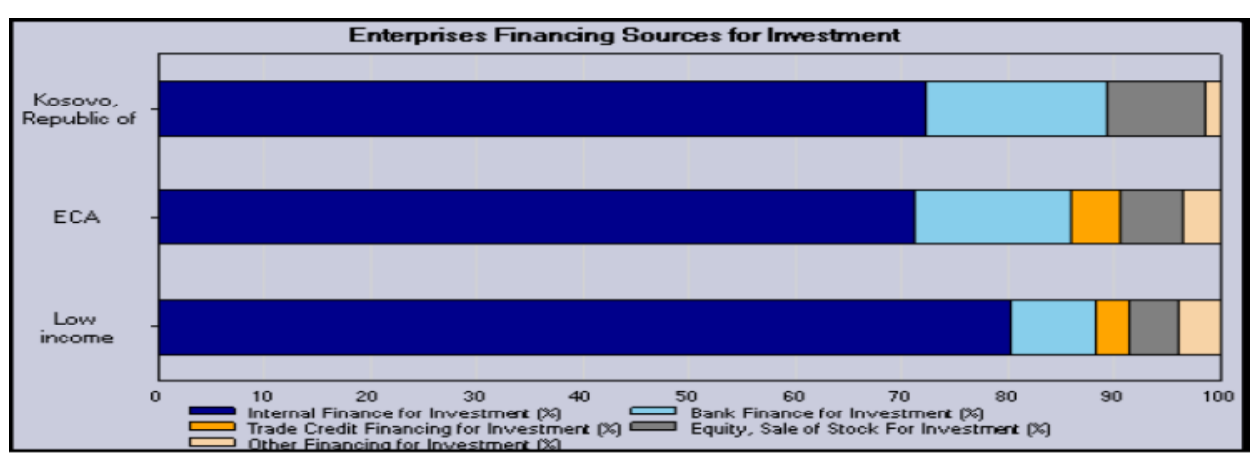

Source: BEEPS (World Bank, 2013)

Financial resources are mobilised only through banking and non-banking institutions, meaning that there is no equity market in the country. Kosovo has adopted a full and modern legal framework which addresses aspects related to investment institutions (EBRD, 2013). ${ }^{7}$ Despite this modern framework, findings indicate that firms operating in Kosovo, particularly SMEs, find it difficult to obtain loans from financial institutions, and these difficulties are linked with insufficient collateral, and a lack of a credit track record (OECD, 2012). The cost of loans is high comparing to other countries in the region. As Table 1 indicates, Kosovo has the widest spread of interest rates in the region.

Table 1 Interest rate spreads (lending minus deposit rate) 2009-2012

\begin{tabular}{lcccc}
\hline Alb & 5.9 & 6.4 & 6.6 & 5.5 \\
Cro & 8.4 & 8.6 & 8 & 7.6 \\
Kos & 10.1 & 10.9 & 10.2 & 9.1 \\
FYROM & 3 & 2.4 & 3 & 3.4 \\
Mne & 5.5 & 5.8 & 6.6 & 6.3 \\
Srb & 6.7 & 6 & 7.4 & 7.6 \\
\hline
\end{tabular}

Source: World Bank (2012)

The wide spread of interest rates between deposits and loans is seen to be as a result of market bank inefficiencies, such as high transaction costs and asymmetric information (Stiglitz and Weiss, 1981). The main transaction costs included here are those related to 
selecting, analysing the quality and monitoring of the borrowers. The higher these inefficiencies are, the higher the interest spread will be.

In conclusion, the evidence presented above shows that national economic institutions that shape social conditions of innovative enterprise exist in the country, and in general they are compatible with modern European Union standards. It is an overall impression that the major problem lies in the weak implementation of these institutions in practice. This is specifically evident with implementation of legislation related to employment and labour relations, labour market flexibility, easiness to hire or lay-off employees, reward systems, corporate governance practices, etc. One of the major shortcomings relating to the poor social conditions at macro level has to do with the capacity of the society to provide the population with qualitative and modern education, training, and access to research. This system suffers from numerous weaknesses. Findings indicate that graduates in Kosovo lack applied skills, and due to the absence of applied training and soft skills, graduates struggle to find jobs after graduation. The entire higher education system in Kosovo is characterised by a marginalisation of scientific research. Kosovo has the lowest investment rate in the R\&D activities. The existing research institutions suffer from a lack of research capacity and also applied research is under developed. Despite the fact that the financial system seems to be stable and well regulated, the evidence shows that cost of finance is higher than in comparator countries.

\section{Empirical results at the firm level}

In the following section are examined social conditions at micro-level. The aim is to investigate the ways in which business executives allocate resources, manage the labour force, organise and integrate the innovation activities, and deal with financial interests for the sake of generating higher quality products at lower unit costs. For this study, the ability to export is assumed as an outcome, or degree of success of an innovative firm, and it is used throughout this section to investigate innovation based factors (strategic control, organisational integration, and investment commitment) that differentiate this type of firm from other non-exporting firms. ${ }^{8}$ Innovative firms are here those that generate products and process new to the firm, not necessarily new to the market or internationally. Therefore, the aim of the following section is to explore what are those factors/variables that differentiate firms that are able to export/innovate from those that cannot do that. The statistical technique used is the logistic regression, which is essentially similar to linear regression analysis except that the outcome is dichotomous - exporting/non exporting (Austin et al., 1989). It makes use of mathematical models to describe relationships. The outcome in logistic regression analysis is often coded as 0 or 1 , where 1 indicates that the outcome of interest is present, and 0 indicates that the outcome of interest is absent. As stated in the section of methodology and data, the analysis is conducted using a dataset generated from a firm-level survey with a sample of 500 firms conducted in December 2012. ${ }^{9}$

The descriptive statistic outcomes indicate that from the total number of firms, only $5.9 \%$ of them are exporting/innovating firms. In terms of the ownership structure, $89 \%$ of firms belong to sole owners, $5 \%$ to partnerships, while only $5.9 \%$ belong to limited liability firms. Also in terms of sectors, the findings show that around $13 \%$ of firms belong to the manufacturing sectors, while the majority of them belong to trading $(57.9 \%)$ and other service sectors $(29.4 \%)$. 


\subsection{Empirical results on strategic control factors}

In order for firms to innovate, resources must be allocated strategically. According to Lazonick (2013), this element of social conditions involves a set of relations that gives decision-makers power to allocate the firm's resources to confront technological, market, and competitive uncertainties that are inherent in the innovation processes. Those that occupy such positions must have both the abilities and the incentives to allocate resources to innovative investment strategies. Their abilities are the function of acquired education, knowledge, experience, and training, while their incentives depend on whether the interests of strategic decision-makers are in line with the interest of the firm they manage. Therefore, from the perspective of the theory of innovative firm it is important to understand who are those that manage the firm, namely whether the firm is run by owners, managers, or by both of them, and how their interests are aligned with the strategy of the firm.

Five explanatory variables have been used to investigate the differences between two groups of firms: structure and characteristics of the ownership, concentration of ownership (minorities and majority owners), interactions between managers and owners. With regard to the abilities of those who have power to take decision to allocate strategically internal resources into innovation activities, the variables used include the educational attainment of decision-makers, experiences accumulated over the years, and the organisation of training activities.

As Table 2 shows, exporting based firms differ considerably from non-exporting firms in terms of ownership structure, power distribution, educational attainment, and management training.

Table 2 descriptive statistics on strategic control indicators (N: 500)

\begin{tabular}{lcccc}
\hline Variable & & Total sample & Exporting & Non-exporting \\
\hline Ownership & One owner & 87.0 & 48.0 & 90.3 \\
structure & More than two owners & 12.9 & 52.0 & 9.7 \\
Power distribution & Owner & 80.0 & 25.9 & 79.8 \\
& Manager & 20.0 & 74.1 & 20.2 \\
Experience before & Experience & 44.2 & 48.1 & 37.2 \\
starting business & Non-experience & 55.8 & 51.9 & 62.8 \\
Formal education & University degree holder & 29.2 & 81.5 & 37.0 \\
& Secondary school & 70.8 & 18.5 & 63.0 \\
Management & Training & 37.2 & 70.4 & 27.9 \\
training & No training & 62.8 & 29.6 & 72.1 \\
\hline
\end{tabular}

Source: BSCK 2012

In order to understand whether the differences have statistical significance, the direct logistic regression was performed. Before the exercise was conducted, the model was tested to meet the necessary requirements for this specific statistical technique. The model contains five above mentioned explanatory. The full model containing all predictors was statistically significant, $\chi^{2}(4, \mathrm{~N}=500)=50.937, \mathrm{p}<.000$, indicating that the model was able to distinguish between firms which reported and did not report the exporting activities. The model as a whole explained between 15.41\% (Cox and Snell R 
square) and $36.3 \%$ (Nagelkerke R squared) of the variance in exporting, and correctly classified $93.5 \%$ of cases. As shown in Table 2, all the explanatory variables made a unique statistically significant contribution to the model. The strongest predictor of the differentiation between two groups of firms was the ownership concentration variable with $\mathrm{p}$ equal to 0.001 , followed by power distribution variable with $\mathrm{p}=0.07$. With positive odds associated for both these variables, it could be interpreted that firms that are owned by more than two owners are 5.3 times more likely to report to be engaged in exporting activities, and 4.1 times if decision making power is concentrated on managers rather than on owners. Two other statistically significant variables also have positive B values, indicating that firms which are managed by people with better education, and firms that are engaged in management training 3.1 (educational attainment) and 3.6 (training activities) times are more likely to report exporting activities than the other group of firms.

Table 3 Logistic regression results on strategic factors

\begin{tabular}{|c|c|c|c|c|c|c|c|c|c|}
\hline & & & & & $\begin{array}{c}\text { Cox and } \\
\text { Snell } R \text { sq. }\end{array}$ & $D$ & Odds & $90 \% \mathrm{C}$ & I. Odds \\
\hline & $B$ & S.E & Wald & $d f$ & $\begin{array}{l}\text { Nagelkerke } \\
\quad \text { R. sq. }\end{array}$ & 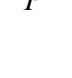 & Ratio & Lower & Upper \\
\hline $\begin{array}{l}\text { Ownership } \\
\text { structure }\end{array}$ & 1.665 & .500 & 11.095 & 1 & & .001 & 5.284 & 1.984 & 14.073 \\
\hline $\begin{array}{l}\text { Power } \\
\text { distribution }\end{array}$ & 1.399 & .516 & 7.366 & 1 & & .007 & 4.052 & 1.475 & 11.128 \\
\hline $\begin{array}{l}\text { Formal } \\
\text { education }\end{array}$ & 1.122 & .560 & 4.015 & 1 & 36.3 & .045 & 3.072 & 1.025 & 9.211 \\
\hline $\begin{array}{l}\text { Management } \\
\text { training }\end{array}$ & 1.281 & .511 & 6.273 & 1 & 96.5 & .012 & 3.600 & 1.321 & 9.810 \\
\hline Expert before & .023 & .501 & .002 & 1 & & .963 & 1.023 & .384 & 2.730 \\
\hline Constant & -.605 & .465 & 1.694 & 1 & & .193 & .546 & & \\
\hline
\end{tabular}

Source: BSCK 2012

Based on these outcomes, it can be inferred that strategic control factors matter when it comes to the ability of firms to engage in exporting and innovative activities. Education and knowledge, as well as other working skills are shown to be crucial factors for enhancing firm performance. Specific firm training - as it is the case with management training - can therefore increase the competency of managers and workers, competency which gradually becomes a strategic control asset. Benefits of training, accumulated from the past, builds 'bundles' of routines that can be difficult to understand and imitate (Koch and McCrath, 1996). They can also improve competitive advantage and consequently lead to superior performance. In summary, the results obtained from the regression exercise indicate that ownership structure, distribution of power, educational attainment, and organisation of training sessions for managers can be significant predictors to the greater business success.

\subsection{Empirical results on organisational integration factors}

The implementation of an innovative activity requires organisation, i.e., it requires a social condition that integrates different hierarchical responsibilities and functional 
capabilities which end up with the production of higher quality, low cost products and services (Lazonick, 2012). More specifically, this element of the social conditions includes a set of relations that enable firms to transform inputs into innovative outputs. As Lazonick (2013) asserts, the need for organisational integration derives from the developmental complexity of innovation process - that is, the need for organisational learning.

Seven explanatory variables were used to investigate the sources of organisational learning that differentiate two groups of firms. As Table 4 indicates, four of them appear to be significant differentiating factors between two groups of firms.

Table 4 descriptive statistics on organisational indicators (N:500)

\begin{tabular}{lcccc}
\hline Variable & & Total sample & Exporting & Non-exporting \\
\hline Business plan & Yes & 23.3 & 70.4 & 29.3 \\
& No & 76.7 & 29.6 & 70.7 \\
Collaboration & Yes & 45.6 & 52.6 & 44.5 \\
& No & 54.4 & 47.4 & 55.5 \\
Market as source of & Important & 44.2 & 70.4 & 41.6 \\
learning & Not important & 55.8 & 29.6 & 58.4 \\
Staff's ideas as & Important & 39.5 & 51.9 & 39.3 \\
source of learning & Not important & 60.5 & 48.1 & 60.7 \\
Tried to innovate & Yes & 13.9 & 44.4 & 6.5 \\
by failed & No & 86.1 & 55.6 & 93.5 \\
Change of & Yes & 13.5 & 22.2 & 9.5 \\
marketing strategy & No & 86.5 & 77.8 & 90.5 \\
Foreign partners & Yes & 11.6 & 51.9 & 10.3 \\
& No & 88.4 & 48.1 & 89.7 \\
\hline
\end{tabular}

Source: BSCK 2012

A logistic regression was performed to ascertain the effects of business plan, market as source of for learning, the willingness of firms for risk taking, the ability to change marketing strategy according to market needs, and finally having a foreign business partner, on the likelihood that firms will report any exporting activity. The logistic regression model was statistically significant, $\chi^{2}(5)=60.982, p<.0000$. The model explained $37.0 \%$ (Nagelkerke $\mathrm{r}^{2}$ ) of the difference between exporting and non-exporting firms and correctly classified $93.9 \%$ of cases. As shown in Table 4, from five variables included, four of them made a unique statistically significant contribution to the model. The strongest predictor of reporting a difference between two groups of firms was the willingness of firms to undertake business innovation activities regardless of the possibility to fail, recording an odds ratio of 7.7. This odd ratio indicated that firms that take business risks are seven times more likely to be engaged in exporting activities than firms that do not take business risks, controlling for all other factors in the model. The second strongest predictor of the difference between two groups of firms is the capacity of firms to link with foreign partners. This variable has an odds ratio of 6.2 , indicating that exporting firms were around six times more likely to report the relationship with foreign partners as a significant factor for conducting exporting business activities. 
Organising business activities based on a business plan, with an odds ratio of 5.8, also seems to be a significant predictor in explaining. Evidence suggests that exporting firms are 2.6 times more likely to report the market as a source of learning than non-exporting firms. The least effect on the variance between two groups of firms seems to have been the ability of firms to change marketing strategy according to market demands.

Table 5 Logistic regression results on organisational integration

\begin{tabular}{|c|c|c|c|c|c|c|c|c|c|}
\hline & & & & \multirow{2}{*}{\multicolumn{2}{|c|}{$\begin{array}{c}\text { Cox and } \\
\text { Snell R sq. } \\
\text { Nagelkerke } \\
\text { R. sq. }\end{array}$}} & \multirow{2}{*}{$P$} & \multirow{2}{*}{$\begin{array}{c}\text { Odds } \\
\text { Ratio }\end{array}$} & \multicolumn{2}{|c|}{$90 \%$ C.I. Odds } \\
\hline & $B$ & S.E & Wald & & & & & Lower & Upper \\
\hline Business plan & 1.753 & .511 & 11.785 & 1 & & .001 & 5.774 & 2.122 & 15.713 \\
\hline $\begin{array}{l}\text { Market as } \\
\text { source of } \\
\text { learning }\end{array}$ & .961 & .502 & 3.671 & 1 & & .055 & 2.615 & .978 & 6.989 \\
\hline $\begin{array}{l}\text { Staff's ideas } \\
\text { as source of } \\
\text { learning }\end{array}$ & -.137 & .496 & 0.076 & 1 & & .783 & 0.872 & .330 & 2.307 \\
\hline $\begin{array}{l}\text { Attempting to } \\
\text { innovate but } \\
\text { failed }\end{array}$ & 2.047 & .510 & 16.110 & 1 & & .000 & 7.743 & 2.850 & 21.035 \\
\hline $\begin{array}{l}\text { Change of } \\
\text { marketing } \\
\text { strategy }\end{array}$ & -.421 & .600 & .491 & 1 & 0.15 & .483 & .657 & .202 & 2.129 \\
\hline $\begin{array}{l}\text { Collaboration } \\
\text { (other } \\
\text { institutes and } \\
\text { firms inside } \\
\text { the country) }\end{array}$ & -.155 & .530 & .085 & 1 & 0.37 & .770 & .857 & .303 & 2.421 \\
\hline $\begin{array}{l}\text { Foreign } \\
\text { partners }\end{array}$ & 1.829 & .469 & 15.206 & 1 & & .000 & 6.230 & 2.484 & 15.625 \\
\hline Constant & -1.233 & .636 & 3.754 & 1 & & .053 & .291 & & \\
\hline
\end{tabular}

Source: BSCK 2012

The empirical outcomes obtained from both exercises indicate that factors that enable the integration of organisational activities matter. More specifically the results indicate that risk-taking capability is significant factor. This indicates that exporting firms effectively organise strategic resources, and exploit new opportunities, and specifically launch projects with uncertain outcomes and tentative projected returns on investment (Scheepers et al., 2008). It is expected that new projects involve risks, which can be minimised either by the knowledge residing in the firm, by unique capabilities or collaboration with other firms, specifically with foreign partners. Collaboration with foreign partners is another specific differentiating factor emerging from the analysis. Through collaboration with foreign partners, firms share resources including: ideas, know-how, technologies, and staff between two or more organisations in order to create a solution to a given problem (Lawton Smith and Dickson, 2003). Partnerships with foreign firms can also minimise risks which arise when firms test markets, and in this manner over time they assimilate risk-taking capabilities which makes them more successful than others (Scheepers et al., 2008). 


\subsection{Empirical results on investment commitment}

The innovation process is not an act, but rather a process that cumulates over time (Lazonick, 2013). By being so, the process needs sustained commitment of financial resources to keep it evolving. This is an essential social condition that enables firms to sustain the cumulative innovation process until it turns into financial profit. In Lazonick's words, implementing innovative projects through internal revenues is a very critical form of financial commitment, but such inside finance must often be supplemented by external sources. In the following figure is given a descriptive statistics which shows that exporting firms have been more active in investing in new projects and technologies comparing to non-exporting firms.

Table 6 statistical summary of investment commitment variables

\begin{tabular}{|c|c|c|c|c|c|c|}
\hline & \multicolumn{2}{|c|}{$\begin{array}{l}\text { Invested in last } \\
\text { three years }\end{array}$} & \multicolumn{2}{|c|}{$\begin{array}{l}\text { Loans from financial } \\
\text { institutions }\end{array}$} & \multicolumn{2}{|c|}{ Terms of loans } \\
\hline & Yes (\%) & No (\%) & Yes $(\%)$ & No (\%) & $<3$ years & $>3$ years \\
\hline Total firms & 55.3 & 44.7 & 53.8 & 46.2 & 78 & 22 \\
\hline Exporting firms & 65.4 & 34.6 & 59.3 & 40.7 & 66.7 & 33.3 \\
\hline Non-exporting firms & 35.9 & 64.1 & 27 & 73 & 76.1 & 23.9 \\
\hline
\end{tabular}

Source: BSCK 2012

The generally short time duration and the high interest rates indicate that the component of social condition related to finance is not favourable. $83 \%$ of respondents mentioned lack of collateral as the main reason for not obtaining bank loans. It appears that due to the adverse perception of risk; banks demand high amounts of collateral in order to issue loans.

Table 7 Logistic regression results on investment commitment

\begin{tabular}{|c|c|c|c|c|c|c|c|c|c|}
\hline & \multirow[b]{2}{*}{$B$} & \multirow[b]{2}{*}{ S.E } & \multirow[b]{2}{*}{ Wald } & \multirow[b]{2}{*}{$d f$} & \multirow{2}{*}{$\begin{array}{c}\text { Cox and } \\
\text { Snell R sq. } \\
\text { Nagelkerke } \\
\text { R. sq. }\end{array}$} & \multirow{2}{*}{$P$} & \multirow{2}{*}{$\frac{\text { Odds }}{\text { Ratio }}$} & \multicolumn{2}{|c|}{ 90\% C.I. Odds } \\
\hline & & & & & & & & Lower & Upper \\
\hline Investment & 1.006 & .451 & 4.972 & 1 & 0.4 & .026 & 2.734 & 1.129 & 6.618 \\
\hline Loans & 1.079 & .432 & 6.232 & 1 & 0.10 & .013 & 2.943 & 1.261 & 6.869 \\
\hline Constant & 1.626 & .305 & 28.430 & 1 & & .000 & 5.085 & & \\
\hline
\end{tabular}

Source: BSCK 2012

The logistic regression model was statistically significant, $\chi^{2}(2)=14.308, p<.001$. The model explained $10.0 \%$ (Nagelkerke $\mathrm{r}^{2}$ ) of the difference between exporting and non-exporting firms and correctly classified $93.6 \%$ of cases. As shown in Table 6 , the strongest predictor of reporting a difference between two groups of firms was the loans variable, recording an odds ratio of 2.9. This odds ratio indicated that firms that obtain loans are around three times more likely to be engaged in exporting activities than firms that do not take business loans, controlling for all other factors in the model. Similarly, the investment variable turned out to be a significant predictor, having an odds ratio of 2.7. Of course, this model raises the issue of endogeneity as exporters are more likely to 
receive more favourable loans given their supposedly better performance. However, in view of data availability this issue cannot be addressed further.

\section{Discussion}

This study should be viewed in the light of some limitations. First, the questionnaire of the conducted survey was not specifically designed for the purpose of this paper. A greater depth of information may have been obtained if the survey could have included interviewing about some more specific issues, such as the relationships between principals (owners) and agents (managers), about concentration of ownership (majority and minority owners), about industrial relations or interactions between managers and workers which are partly institutionally specific to each country but are also partly firm specific, i.e., firms in similar institutional environment may have quite different intra-firm labour-management relations. Second, the quality of the dataset would be improved by using the case study approach, which could have added important qualitative data and would have also enabled us to gain a greater insight into the way firms organise industrial relations or interactions between managers and labours. Third, this study had not data to analyse the interaction and the effects of the industrial sectors on the innovation capabilities to the macro as well as the micro level.

\section{Concluding remarks}

In this paper was examined the issue of whether the social conditions into which a firm is operating have an effect on its innovation activities. The examination was conducted by using diverse international and national datasets and information, and a firm-level dataset of 500 Kosovo firms. The outcomes obtained confirm the hypothesis that social conditions matter, and after taking macro-social conditions into account, social conditions at micro-level contribute significantly to explain the variation between firms in innovation activities.

The findings show that despite the fact that Kosovo has managed to establish an institutional framework which to a great extent is in line with European Union requirements, the problem remains on the implementation of this legal structure in practice. This legal framework addresses important issues related to the business entity operations such as the enterprise law, tax law, regulations related to employment, corporate governance, etc. Kosovo also has created and adopted a modern institutional framework that covers aspects related to human capital development. But, findings indicate that the current education system does not address properly the demands of the labour market. There is a poor coordination between market needs and graduates generated by both, vocational schools and universities. As one of BEEPS's surveys suggests, around $80 \%$ of companies surveyed in Kosovo consider the level of workers' skills and education to be a major problem for doing business. In terms of investment institutions, the findings suggest that financial system in the country is quite stable, but the cost of credits seems to be significantly higher than in comparator countries. With regards to social conditions at firm-level, the results suggest that from the total number of firms included in the sample, the number of firms endowed with innovative capabilities is 
significantly low $-5,9 \%$. This percentage is the outcome of external conditions of innovative firms as well as of strategic control and organisational integration factors at firm level. In terms of social conditions related to strategic control, findings suggest that majority of firms endowed with innovative capabilities are owned by more than two owners, and usually ownership and management is separated. The results also indicate that innovative firms are run by people who are better educated and better trained as opposed to the other group of firms. In summary, findings suggest that the better the strategic control conditions are, the higher is the likelihood for firms to innovate. With respect to organisational integration component, findings show that factors such as possession of a business plan, the ability to learn from market, adopting a marketing strategy to market needs and demands, the ability and readiness to take business risks, collaboration with foreign business partners, are more likely to have a strong positive influence on the capability of firms to transform inputs into more innovative outputs. Findings in relation to the investment commitment show that the cost of finance is high, and the terms of loans offered to business entities is very short and unfavourable.

These results point to the conclusion that the theory of innovative firm provides a good framework to understand the dynamic interaction between the organisational conditions of firms and the institutional environments in which they operate. In that respect, social conditions for innovative enterprise theory represents a hybrid framework which is able to capture external variables as well as internal variables. Yet, it is distinctively different from other theories (e.g., growth diagnostics, resource-based theory, or management practices approach) which are focused on static issues, i.e., how firms could operate successfully with the given technology. The innovative enterprise theory asks itself what factors inhibit firms improving their technological capabilities. Further, the results of this study show that the social conditions are distinctive sets of factors which should be accounted for when analysing business factors relevant to the growth of firms, not only their current operations. Finally, the methodological and theoretical foundations of the theory of innovative firm could serve as a fertile and exciting framework for future empirical research studies.

\section{References}

Almor, T. (2006) 'Conceptualizing path of growth for the born global firms', Paper presented at the ACCS Annual Conference, Berlin.

Almor, T. and Hashai, N. (2004) 'Competitive advantage and strategic configuration of knowledge-intensive small and medium sized multinationals: a modified resource based view', Journal of International Management, Vol.10, No. 4, pp.479-500.

Austin, J.T., Yaffee, R.A. and Hinkle, D.E. (1989) 'Logistic regression for research in higher education', in Smart, J.C. (Ed.): Higher Education: Handbook of Theory and Research, Vol. 5, pp.379-410, Agathor Press, New York.

Barney, J.B. (1991) 'Firm resources and sustained competitive advantage', Journal of Management, Vol. 17, No. 1, pp.99-121.

Bloom, N. and Van Reenen, J. (2007) 'Measuring and explaining management practices across firms and countries', Quarterly Journal of Economics, Vol. 122, No. 4, pp.1351-1408.

Bresciani, S., Thrassou, A. and Vrontis, D. (2013) 'Change through innovation in family businesses: evidence from an Italian sample', World Review of Entrepreneurship, Management and Sustainable Development, Vol. 9, No. 2, pp.195-215. 
Brunswicker, S. and Vanhaverbeke, W. (2011) Beyond Open Innovation in Large Enterprises: How Do Small and Medium-Sized Enterprises (SMEs) Open Up to External Innovation Sources? [online] SSRN: http://www.ssrn.com/abstract=1925185 (accessed 22 September 2012).

Classen, N., Van Gils, A., Bammens, Y. and Carree, M. (2012) 'Accessing resources from innovation partners: the search breadth of family SMEs', Journal of Small Business Management, Vol. 50, No. 2, pp.191-215.

Collier, D. (1993) 'The comparative method', in Finifter, A.W. (Ed.): Political Science: The State of the Discipline II, pp.105-19, (Washington, D.C.: The American Political Science Association, 1993).

Cooney, R. (2010) 'Exploring skill ecosystems in the Australian meat processing industry: unions, employers and institutional change', Economic and Labour Relations Review, Vol. 21, No. 2 , pp.121-138.

Davidsson, P. and Honig, B. (2003) 'The role of social and human capital among nascent entrepreneurs', Journal of Business Venturing, Vol. 18, No. 3, pp.301-331.

EBRD (2013) Commercial Laws of Kosovo, An assessment by EBRD [online] http://www.ebrd.com/downloads/sector/legal/kosovo.pdf (accessed 22 March 2014).

European Commission (EC) (2010) 'Internationalisation of European SMEs', Directorate-General for Enterprise and Industry, Brussels [online] http://www.ec.europa.eu/enterprise/ policies/sme/market-access/files/internationalisation_of_european_smes_final_en.pdf (accessed 12 July 2012).

European Commission (EC) (2011) Commission Staff Working Paper, Kosovo* 2011 Progress Report, EC, Brussels.

European Commission (EC) (2012) European Commission - Enlargement - Potential Candidates - Kosovo* [online] http://ec.europa.eu/enlargement/potentialcandidates/Kosovo*/financialassistance/index_en.htm (accessed 23 July 2012; accessed 21 August 2013).

Fagerberg, J. (2001) 'The economic challenge for Europe: adapting to innovation-based growth', in Archibugi, D. and Lundvall, B-Å. (Eds.): The Globalising Learning Economy: Major Socio-Economic Trends and European Innovation Policy, Oxford University Press, Oxford.

Freel, M.S. (2005) 'Patterns of innovation and skills in small firms', Technovation, Vol. 25, No. 4, pp.123-134.

Freeman, J., Styles, C. and Lawley, M. (2012) 'Does firm location make a difference to the export performance of SMEs?', International Marketing Review, Vol. 29, No. 1, pp.88-113.

Golovko, E. and Valentini, G. (2011) 'Exploring the complementarity between innovation and export for SMEs' growth', Journal of International Business Studies, Vol. 42, No. 3, pp.362-380.

Gust-Bardon, N.I. (2014) 'Regional development in the context of an innovation process', Int. J. of Innovation and Regional Development, Vol. 5, Nos. 4/5, pp.349-366.

Hausmann, R., Bailey, K. and Rodrigo, W. (2008) Doing Growth Diagnostics in Practice: A 'Mindbook', Harvard University Center for International Development Working Paper 177.

He, Z.L. and Wong, P.K. (2012) 'Reaching out and reaching within: a study of the relationship between Innovation collaboration and innovation performance', Industry and Innovation, Vol. 19, No. 7, pp.539-561.

Herrmann, A.M. and Peine, A. (2011) 'When 'national innovation system' meet 'varieties of capitalism' arguments on labour qualifications: on the skill types and scientific knowledge needed for radical and incremental product innovations', Research Policy, Vol. 40, No. 5, pp.687-701.

Hewitt-Dundas, N. and Roper, S. (2009) 'Output additionality of public support for innovation: evidence for Irish manufacturing plants', European Planning Studies, Vol. 18, No. 1, pp.107-122.

Jones, M.V. (2001) 'First steps in internationalisation: concepts and evidence from a sample of small high-technology firms', Journal of International Management, Vol. 7, No. 3, pp.191-210. 
Kanter, R.M. (2000) 'When a thousand flowers bloom: structural, collective, and social conditions for innovation in organizations', in Staw, B. and Sutton, R. (Eds.): Research in Organizational Behavior, Vol. 22, Elsevier Science, Amsterdam, Netherlands.

Keupp, M.M., Palmié, M. and Gassmann, O. (2012) 'The strategic management of innovation: a systematic review and paths for future research', International Journal of Management Reviews, Vol. 14, No. 4, pp.367-390.

Knight, G. and Cavusgil, T. (2004) 'Innovation, organizational capabilities, and the born-global firm', Journal of International Business Studies, Vol. 35, No. 2, pp.124-141.

Koch, M.J. and McCrath, R.G. (1996) 'Improving labour productivity: human resource management policies do matter', Strategic Management Journal, Vol. 17, No. 5, pp.335-354.

Lawton Smith, H. and Dickson, K. (2003) 'Critical factors in inter-firm collaboration', International Journal of Technology Management, Vo. 25, Nos. 1/2, pp.34-50.

Lazonick, W. (2012) 'Who need the theory of innovative enterprise', Paper represented at the Annual Conference of the International Schumpeter Society, 2-5 July, Brisbane, Australia.

Lazonick, W. (2013) 'The theory of innovative enterprise: methodology, ideology, and institutions', in Moudud, J.K., Bina, C. and Mason, P.L. (Eds.): Alternative Theories of Competition: Challenges to the Orthodoxy, pp.127-159, Routledge, Abingdon, UK.

Lazonick, W., Mazzucato, M. and Tulum, Ö. (2013) 'Apple's changing business model: what should the world's richest company do with all those profits?', Accounting Forum, Vol. 37, No. 4, pp.249-267.

Leiponen, A. (2005) 'Skills and innovation', International Journal of Industrial Organization, Vol. 23, Nos. 5/6, pp.303-323.

Lichtenthaler, U. and Muethel, M. (2012) 'The impact of family involvement on dynamic innovation capabilities: evidence from German manufacturing firms', Entrepreneurship Theory and Practice, Vol. 36, No. 6, pp.1235-1253.

Love, J. and Roper, S. (2013) SME Innovation, Exporting and Growth, Enterprise Research Center White Paper, No. 5.

Love, J.H., Roper, S. and Du, J. (2009) 'Innovation, ownership and profitability', International Journal of Industrial Organization, Vol. 27, No. 3, pp.424-434.

Melkas, H. and Pekkarinen, S. (2016) 'SMEs and regional design services for innovation: experienced and expected impacts on users and non-users', Int. J. of Innovation and Regional Development, Vol.7, No. 3, pp.222-236.

Murphree, M. Tang, L. and Breznitz, D. (2016) 'Tacit local alliance and SME innovation in China', Int. J. of Innovation and Regional Development, Vol. 7, No. 3, pp.184-202.

Nathan, M. (2013) Top Team Demographics, Innovation and Business Performance: Findings from English Firms and Cities 2008-9, SERC Research Paper No. SERCDP0129.

OECD (2011) Skills for Innovation and Research, OECD, Paris, 96.

OECD (2012) SME Policy Index: Western Balkans and Turkey 2012: Progress in the Implementation of the Small Business Act for Europe, OECD Publishing, Paris, DOI: http://dx.doi.org/10.1787/9789264178861-en (accessed 22 October 2012).

OECD (2013a) Assessment of the Kosovo Innovation System, RCI Project Paper, OECE Development, March.

OECD (2013b) Defining Innovation [online] http://www.oecd.org/site/innovationstrategy/ defininginnovation.html (accessed 29 June 2014 ).

Østergaard, C.R., Timmermans, B., Kristinsson, K., (2011) 'Does a different view create something new? The effect of employee diversity on innovation', Research Policy, Vol. 40, No. 3 , pp.500-509, DOI: 10.1016/j.respol.2010.11.004.

Pellegrino, G., Piva, M. and Vivarelli, M. (2009) How do Young Companies Innovate?, Discussion Paper IZA DP, No. 4301 [online] http://www.ftp.iza.org/dp4301.pdf (accessed 12 April 2013). 
Rodríguez, J.C., Navarro-Chávez, L. and Gómez, M. (2014) 'Regional innovation systems in emerging economies: evidence of system failures for innovation', Int. J. of Innovation and Regional Development, Vol. 5, Nos. 4/5, pp.384-404.

Scheepers, M.J., Hough, J. and Bloom, J.Z. (2008) 'Nurturing the corporate entrepreneurship capability', Southern African Business Review, Vol. 12, No. 3, pp.50-75.

Shapira, P., Youtie, J. and Kay, K. (2011) 'Building capabilities for innovation in SMEs: a cross-country comparison of technology extension policies and programmes', Int. J. of Innovation and Regional Development, Vol. 3, Nos. 3/4, pp.254-272.

Stiglitz, J. and Weiss, A. (1981) 'Credit rationing in markets with imperfect information', American Economic Review, Vol. 71, No. 3, pp.393-409.

Ughetto, E. (2008) 'Does internal finance matter for R\&D? New evidence from a panel of Italian firms', Cambridge Journal of Economics, Vol. 32, No. 6, pp.907-925.

UNESCO (2012) Data Centre, UNESCO Institute for Statistics [online] http://www.stats.uis.unesco.org/unesco/TableViewer/document.aspx?ReportId=136\&IF_Lang uage $=$ eng\&BR_Topic $=0$ (accessed 25 November 2012).

Vossen, R.W. (1998) 'Relative strengths and weaknesses of small firms in innovation', International Small Business Journal, Vol. 16, No. 3, pp.88-95, p.90.

World Bank (2010) BEEPS At-A-Glance 2008 Kosovo, Business Environment and Enterprise Performance Survey (BEEPS IV), World Bank, Washington D.C.

World Bank (2013) BEEPS 2013, Kosovo, Business Environment and Enterprise Performance Survey (BEEPS IV), World Bank, Washington DC [online] http://www.enterprisesurveys. org/ /media/GIAWB/EnterpriseSurveys/Documents/Profiles/English/kosovo-2013.pdf (accessed 13 December 2014).

World Bank (2016a) Doing Business 2016 - Measuring Regulatory Quality and Efficiency, World Bank, Washington D.C.

World Bank (2016b) The World Bank in Kosovo Country Snapshot, World Bank, Washington DC.

World Bank (2012) South East Europe Regular Economic Report No. 3, From Double Dip recession to Accelerated Reforms, World Bank [online] http://www.worldbank.org/ content/dam/Worldbank/document/SEERER 3 Report FINAL eng.pdfhttp://www. doingbusiness.org/ /media/giawb/doing\%20 business/documents/profiles/country/KSV.pdf (accessed 27 December 2012).

USAID (2010) USAID/Kosovo Strategic Plan 2010-2014, 20 May.

\section{Notes}

1 The following paragraph is taken from the Lazonick's (2013) explanation on innovation. "Innovation is uncertain because when investments in transforming technologies and accessing markets are made the financial returns cannot be known, even probabilistically. As we shall see, 'optimisation' is the enemy of innovation. Innovation is collective because, to generate higher quality, lower cost products than were previously available, the business enterprise must integrate the skills and efforts of large numbers of people with different hierarchical responsibilities and functional capabilities into the organisational learning processes that are the essence of innovation. Innovation is cumulative because collective learning today provides the foundation for collective learning tomorrow, and these organisational learning processes must be sustained over time until, through the sale of higher quality, lower cost products, financial returns can in fact be generated".

2 While the neoclassical theory takes technologies and markets as given constraints, and as a result cannot differentiate itself from its equally 'perfect' competitors, from the perspective of the theory of innovative enterprise, innovating firms make investments to transform technologies and access markets that can potentially give it a competitive advantage. Similarly, the transaction cost theory assumes that firms operate under the concepts of 'bounded rationality' and 'opportunism' and 'asset specificity', while this framework argues 
that through its investment strategy and organisational structure, the innovating firm can transform asset specificity, bounded rationality, and opportunism rather than take these conditions as given constraints on its activities (Lazonick, 2013).

3 Product - a good or service that is new or significantly improved. This includes significant improvements in technical specifications, components and materials, software in the product, user friendliness or other functional characteristics. Process - a new or significantly improved production or delivery method. This includes significant changes in techniques, equipment and/or software. Marketing - a new marketing method involving significant changes in product design or packaging, product placement, product promotion or pricing. Organisational - a new organisational method in business practices, workplace organisation or external relations.

4 There are several laws which aim to regulate business activities including the Law on Business Organisations (Law No. 02/L-123, dated 27 September 2007), the Law on Publicly-Owned Enterprises (POEs) (Law no 03/L-087, dated 15 June 2008), the Law On Banks, Microfinance Institutions and Non-Bank Financial Institutions (Law No. 04/L-093, dated 12 April 2012) and the Law on Accounting, Financial Reporting and Audits (Law No. 04/L-014, dated 29 July 2011), as well as the Law on Tax.

5 There are 18 private universities and colleges, and five public universities operating in the country (OECD, 2013a).

6 ECA covers 23 countries.

7 The Law of 29 December 2009 No. 03/L-175 on Public Debt that regulates procedures for public debt issuance by the government of the Republic of Kosovo; the Law of 27 September 2007 No. 02/L-123 on Business Organisations that in Title VII (joint stock companies), Chapter 3 regulates the matter of shares and other securities, and the Law of 30 April 2012 No. 04/L-093 on Banks, Microfinance Institutions and Non-Bank Financial Institutions.

8 Empirical research suggests that exporting firms create sustainable competitive advantages based on unique technologies and innovation, which they leverage worldwide (Almor and Hashai, 2004; Almor, 2006). Furthermore there are empirical studies arguing that exporting firms frequently have a superior capability to perform innovative activities (Almor, 2006; Knight and Cavusgil, 2004). Exporting activities are important especially for small and medium-sized firms as they provide access on information and resources not available internally (Davidsson and Honig, 2003). This may be particularly important for firms operating in low income countries.

9 The details of the survey are given in Appendix A.

\section{Appendix A}

\section{Details of the survey questions on social conditions - BSCK}

The dataset was obtained by Business Support Centre of Kosovo operating in Prishtina. The survey was conducted in December 2012 with a sample of 500 SMEs operating in the country. The purpose of this survey was to identify and subsequently address challenges and problems of SME development for both the individual (entrepreneur) firms and business environment level. The process of designing the survey questionnaire and the sample selection has been supported by numerous experts. In addition, discussions were held with relevant stakeholders and there was also a piloting of the questionnaire. The interviews were conducted face - to face with the key people in each enterprise, mainly owner/managers or financial managers. The questionnaire contained nine sections covering major aspects of entrepreneurship and SME development in Kosovo. The respondents were asked to provide qualitative (their motives for start-up and 
growth, data on enterprise performance, perceptions of the business environment and future prospects) and a quantitative answer on internal characteristics of the respective firm (years in the business, location, size of the company in terms of employment, value of assets, sector of activity, etc.) and information on their innovation activities and information technology. The data for SMEs were collected by the trained team of interviewers at Business Support Centre Kosovo who were students at the Faculty of Economics of the University of Prishtina and of University College of International Management 'GLOBUS'. The sample was drawn randomly from the business register kept at the Ministry of Trade and Industry/Agency for Business Registration. The procedure for selecting the sample size and companies to be interviewed was done in Excel and SPSS using random command. After several testing phases the team decided to do stratifications of the sample by two categories: size of the company and sectors of business activity. This stratification was important because the random sampling yielded unsatisfactory results in terms of representation of medium firms and manufacturing firms. Both these categories were underrepresented in the sample and as such would not have been useful in analysing these categories. Therefore, the stratifications were applied and satisfactory results in terms of statistical representation of the both sector and size class was yielded.

\section{Appendix B}

Labour and workforce development

Figure B1 Problems doing business: labour regulations** (see online version for colours)

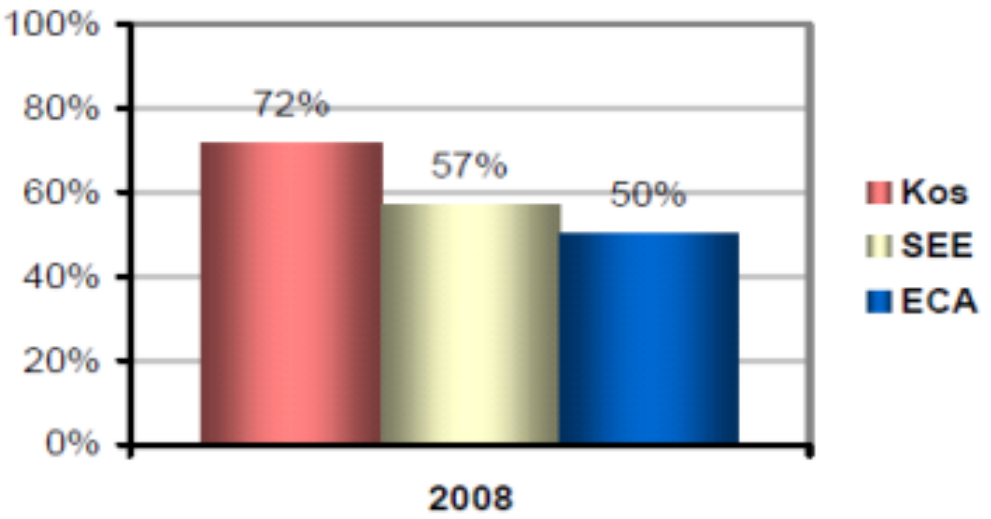

Source: World Bank (2010)

Note: **Percentage of firms indicating labour regulations are not a problem. 
Figure B2 Problems doing business: skills and education of workers** (see online version for colours)

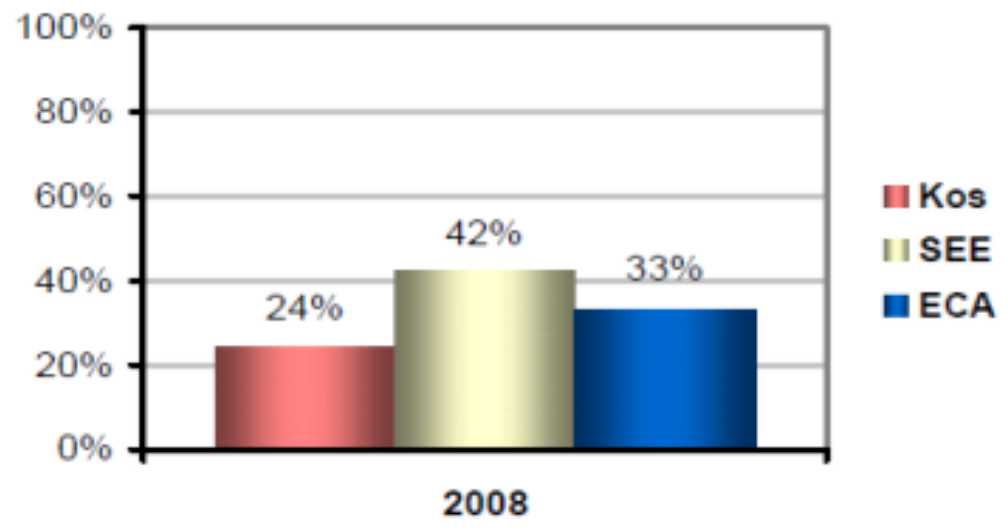

Source: World Bank (2010)

Note: **Percentage of firms indication skills and education of available workers is not a problem.

Figure B3 Professionalism of labour** (see online version for colours)

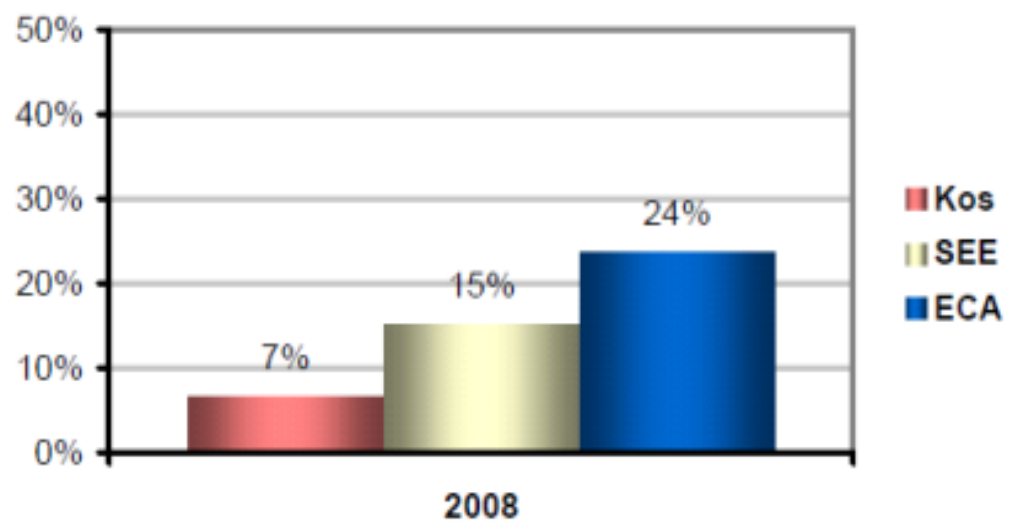

Source: World Bank (2010)

Note: **Percentage of employee that have a university degree or higher. 
Figure B4 Provision of formal training** (see online version for colours)

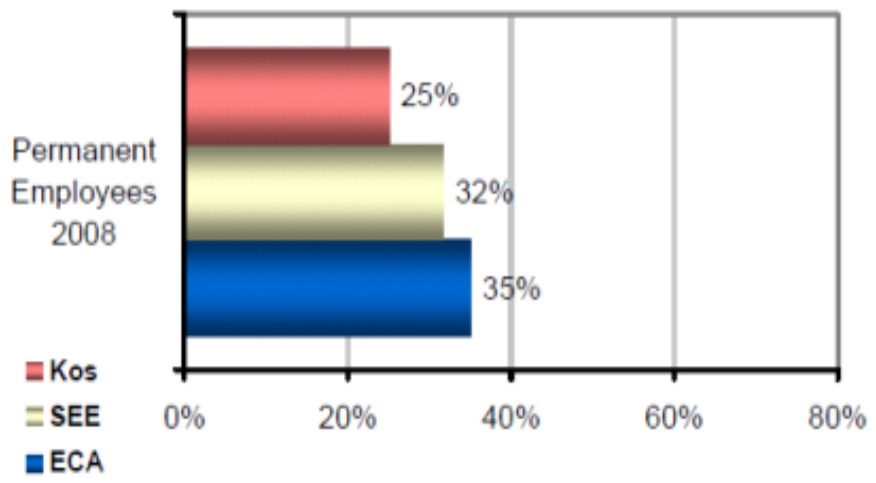

Source: World Bank (2010)

Note: **Percentage of firms offering training for employees.

Figure B5 Percentage of employees trained** (see online version for colours)

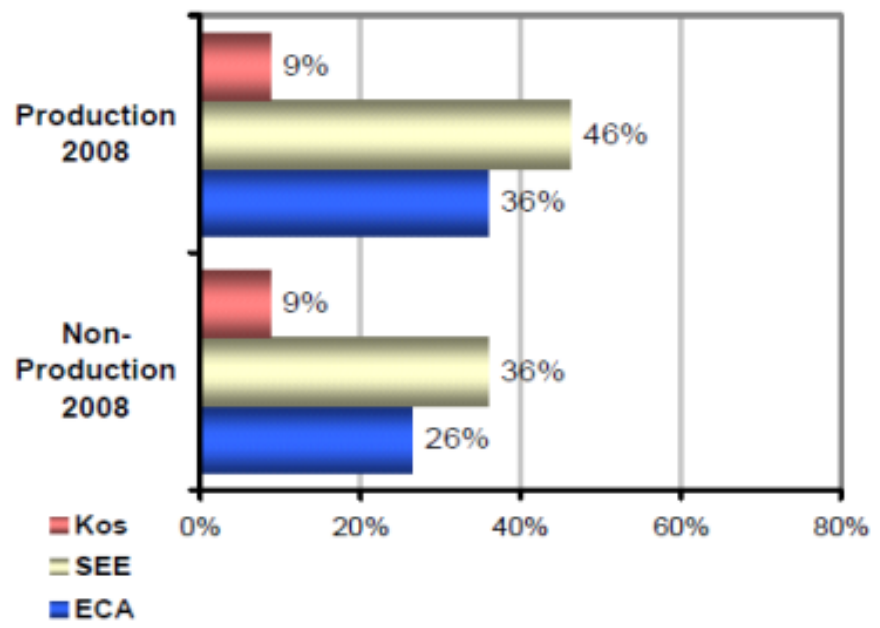

Source: World Bank (2010)

Note: **Percentage of employees participating in training.

\section{Appendix C}

\section{Logistic regression statistical technique}

This technique is similar to linear regression analysis except that the outcome is dichotomous (e.g., success/failure, exporting/non exporting, or yes/no) (Austin et al., 1989). It makes use of mathematical models to describe relationships. The outcome in logistic regression analysis is often coded as 0 or 1 , where 1 indicates that the outcome of 
interest is present, and 0 indicates that the outcome of interest is absent. If $p$ is defined as the probability that the outcome is 1 , the multiple logistic regression model can be written as follows:

$$
\hat{p}=\frac{\exp \left(b_{0}+b_{1} X_{1}+b_{2} X_{2}+\ldots+b_{p} X_{p}\right)}{1+\exp \left(b_{0}+b_{1} X_{1}+b_{2} X_{2}+\ldots+b_{p} X_{p}\right)}
$$

where $\hat{p}$ is the expected probability that the outcome is present; $X_{1}$ through $X_{p}$ are distinct independent variables; and $b_{0}$ through $b_{p}$ are the regression coefficients. In some cases the multiple logistic regression model is written differently. In the following form, the outcome is the expected log of the odds that the outcome is present:

$$
\ln \left(\frac{\hat{p}}{(-\hat{p})}\right) \ln \left(\frac{\hat{p}}{(-\hat{p})}\right)=b_{0}+b_{1} X_{1}+b_{2}+X_{2}+\ldots+b_{p} X_{p}
$$

As it can be noticed, the right hand side of the equation above looks like the multiple linear regression equation. However, the technique for estimating the regression coefficients in a logistic regression model is different from that used to estimate the regression coefficients in a multiple linear regression model. In logistic regression the coefficients derived from the model (e.g., $b_{1}$ ) indicate the change in the expected log odds relative to a one unit change in $X_{1}$, holding all other predictors constant. Therefore, the antilog of an estimated regression coefficient, $\exp \left(b_{i}\right)$, produces an odds ratio.

The application of logistic regression method is based on fulfilment of three requirements. The first one is related to the size and the nature of the sample, namely the data has to be of categorical nature. Wherever required, variables were subject of recoding of their original scores to meet one of the key assumptions and at the same time to ensure their suitability for the analysis. Therefore the Likert-scale scores were transformed into dummy variables, for instance, $1=$ exporting firm, and $0=$ nonexporting firms. The second requirement is multicollinearity, namely cases have been checked for high intercorrelations among predictor (independent) variables, something that was properly dealt by using collinearity diagnostics. Third requirement is related to the presence of outliers. The process was dealt by inspecting all possible residuals. 